\title{
Synthesis of $3^{\prime}$ - 3' - gem - di - $\underline{\mathrm{C}}$-Nitromethyl Nucleoside Analogues of Possible Biological Activity \\ Yousif A. Al-Ftahi ${ }^{*}$, Fuad H.Al - Jawad** , Nidhal F.Al - Mejwel $^{\text {**** }}$ Rece ived 31-8-2002 Accepted 20-2-2005
}

\section{ABSTRACT}

Synthesis of new nucleoside analogues of the type : $3^{\prime}, 3^{\prime}-$ gem-di-C-nitromethly, expected to have useful application in the chemotherapeutic treatment of AIDS, cancer and microbial infections. The synthesis involved the condensation of the appropriate sugar derivative (i.e $.3^{\prime}, 3^{\prime}-$ gem $-\mathrm{di}-\underline{\mathrm{C}}$ - nitromethly -1 - ribofuranose ) with nitrogen bases, such as , uracil and theophllin following a multi step scheme starting from diace tone golucose (1) (scheme 1). The prepared compound were identified by spectroscopic methods; ir, mass, ${ }^{1} \mathrm{H}$ and ${ }^{13} \mathrm{C} \mathrm{nmr}$.

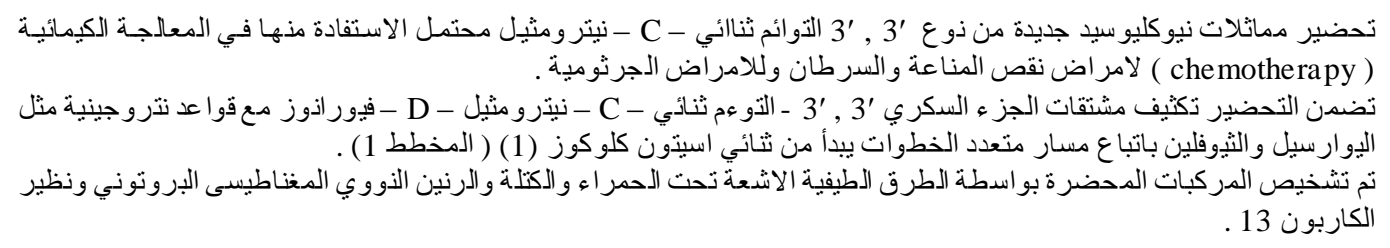

\section{INTRODUCTION}

The $2^{\prime}, 3^{\prime}$ - didexy nucleosides have shown importance in several established chemotherapies (anticancer, antiviral and antibacterial ) and other attractive field like immunomodulation or regulation of gene expression which may constitute new therapeutic approaches ${ }^{(1,3)}$. The board application of modified nucleosides especially in the inhibition of the human immunodeficiency virus (HIV) $)^{(4,5)}$, have targeted the investigation for utilizing new nucleoside analogues .Efforts have primarily focused on modification of the carbohydrate portion of the natural nucleosides because cellular kinases are more tolerant of these changes than changes within the base moiety $^{(6)}$. These observations, have led us to commet the synthesis of a variety of nucleoside analogues contaning $3^{\prime}, 3^{\prime}$ - gem - di $-\underline{\mathrm{C}}$ - nitromethyl substituent at the sugar portion.

\section{MATERIAL and METHOD}

Melting points were determined using electrothermal melting point apparatus and are uncorrected .IR spectra were recorded using either. Shimadzu (408) Jasco (J - 0085 ) infrared spectrophotometer. ' $\mathrm{H}-\mathrm{NMR}$ and ${ }^{13} \mathrm{C}$ - NMR spectra were determined on a Varian XR - 3005 (pharm 300) spectrometer at 299.908 and $75.4118 \mathrm{MHz}$ respectively . $\mathrm{CDC}_{3}$ or DMSO was used as the solvent and TMS as internal standard. General mass spectrometer model 511 valzar was used for recording mass spectra .TLC was performed on glass plants coated with $0.25 \mathrm{~mm}$ layer of silica gel (Fluka) and spot were detected by iodine vapour. Column chromatography was carried out with silica gel 60 ( Fluka ). Uracil from Merk Company . 1,2 : 5,6- Di - $\underline{\mathrm{O}}-$ Isopropylidene $-\propto-\underline{\mathrm{D}}-$ gluc ofuranose $\underline{(1)}$ was prepared from 1,2: 5,6 - Di - $\underline{\mathrm{O}}-$ Is opropylidene $-\propto-\underline{D}$ - ribo - hexofuranose 3 - ulose $(2)$ was prepared as previously described $^{(19,20)}$.

\footnotetext{
* College of Education, Ibn-Al-Haitham, Baghdad University .

** Baghdad College of Pharmacy, Syndicate of Iraqi pharmacists . ***College of pharmacy, University of Baghdad.
} 
1,2 : 5,6 - Di - $\underline{\mathrm{O}}$ - Isopropylidene - $3-\underline{\mathrm{C}}-$ nitromethyl $-\propto-\quad-\mathrm{D}-$ allofuranose $(3)$ and 3 - deoxy - 1,2 :5,6 - di - $\underline{\mathrm{O}}-$ isopropylidene $-3,3-$ gem $-\mathrm{di}-\underline{\mathrm{C}}$ nitromethyl $-\propto-\underline{D}-$ ribo - hexofuranose $\underline{(5)}$ were prepared as previously ${ }^{(7)}$.

3 - Deoxy - 1,2 :5,6 - di - O - is opropylidone $-3-\underline{C}-$ nitromethylene $-\propto-D-$ ribo hexofuranose (4) was prepared according to the method described ${ }^{(21)}$.Bis (theophylline -7 - yl )mercury (10) was prepared as in the method described ${ }^{(12)} .2,4$ - Bis (trimethylisly uracial (13) was synthesized as described before ${ }^{(15)}$.

3 - Deoxy - 1,2 :5,6 - di - O isopropylidene $-3,3$ - gem $-\mathrm{di}-\underline{\mathrm{C}}-$ nitromethyl $-\propto-D-$ ribo hexofuranose (6)

3 - Deoxy - 1,2 :5,6 - di O - isopropylidene $-3,3$ - gem - di - $\underline{C}$ nitromethyl $-\propto-D-$ ribohexofuranose $(5)(8.3 \mathrm{~g}, 22.9 \mathrm{mmol})$ was dissolved in methanol and $\mathrm{IN} \mathrm{H}_{2} \mathrm{SO}_{4}(30 \mathrm{ml})$ was added. The reaction mixture was left to stand at room temperature for $3 \mathrm{hr}$. The resulting mixture was then neutralized by adding solid sodium hydrogen carbonate and then extracted with chloroform .The chloroform extract was dried over anhydrous sodium sulphate and gave upon evaporation the diol (6) as a syrup $(6.0 \mathrm{~g}$, $80.4 \%)$.IR(s mear)v(3450) $\mathrm{cm}^{-1}(\mathrm{OH})$.

3 - Deoxy - $1,2-\underline{\mathbf{O}}-$ isopropylidene $-3,3-$ gem $-\mathrm{di}-\underline{\mathrm{C}}$ - nitromethyl - $\propto-\underline{\mathbf{D}}-$ ribo furanose (7)

The diol $\underline{(6)}(2 \mathrm{~g}, 6.2 \mathrm{mmol})$ was dissolved in ethanol $(40 \mathrm{ml})$ and well - stirred, then saturated solution of sodium hydrogen carbonate $(2 \mathrm{ml})$ was added followed by a solution of sodium metaperiodate $(1.32 \mathrm{~g}, 6.2$ mmol ) in $70 \mathrm{ml}$ water the resulting reaction mixture was stirred $3 \mathrm{hr}$ after which the excess sodium metaaperidate was destroyed by adding few drops of ethylene glycol .The resulting aldehydo sugar was immediately reduced with sodium borohydride $(012 \mathrm{~g})$.After the reaction mixture was kept with stirring for $4 \mathrm{hr}$, acetone $(0.5 \mathrm{ml})$ was added and the mixture was further stirred for 30 minutes. The solid residue was removed by filtration and the filtrate was extracted with methylene chloride, dried over anhydrous sodium sulphate the solvent was removed to give (7) as a syrup $(1.39 \mathrm{~g}$, $76.8 \%$ ). IR (smear )v(3450) $\mathrm{cm}^{-1}(\mathrm{OH}) .{ }^{1} \mathrm{H}$ NMR $\delta 5.82(\mathrm{~d}, 1 \mathrm{H}, \mathrm{H}-1) 4.72-4.70(\mathrm{q}, 1 \mathrm{H}, \mathrm{H}$ - 4 ), $4.66-4.60(\mathrm{~d}, 1 \mathrm{H}, \mathrm{H}-2), 4.10(\mathrm{~s}, 4 \mathrm{H}$, $\left.2 \mathrm{CH}_{2} \mathrm{NO}_{2}\right), 3.53\left(\mathrm{~d}, 2 \mathrm{H}, \mathrm{H}-5, \mathrm{H}-5^{\prime}, 1.38-\right.$ $1.23\left(2 \mathrm{~s}, 6 \mathrm{H}, 2 \mathrm{CH}_{3}\right) .{ }^{13} \mathrm{C}-\mathrm{NMR} \delta 104.32(\mathrm{C}-$
$1), 81.95(\mathrm{C}-2), 58.74,58.40(\mathrm{C}-3), 81.74$

$(\mathrm{C}-4), 84.19(\mathrm{C}-5), 80.31,78.42$

$\left(\mathrm{CH}_{2} \mathrm{NO}_{2}\right), 110.51\left(\mathrm{O}-\mathrm{CMe}_{2}-\mathrm{O}\right), 26.52$,

$26.06, .-\mathrm{C}\left(\mathrm{CH}_{3}\right)_{2}$.

5 - O - Benzoyl - 3 - deoxy - 1,2 - $\underline{\mathbf{O}}$ - isopropylidene $-3,3$ - gem $-\mathrm{di}-$

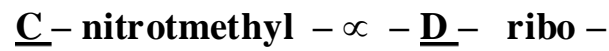
furanose (8)

The 3-deoxy - 1,2-O - isopropylidene 3,3 - gem - di - C nitromethyl - $\propto-\underline{D}$ ribofuranose (7) $(2.4 \mathrm{~g}, 8.2 \mathrm{mmol})$ was dissolved in anhydrous pyridine $(6.7 \mathrm{ml}, 83$ mmol ) after external cooling with ice , benzoyl chloride $(0.96 \mathrm{ml} ; 8.3 \mathrm{mmol})$ was added dropwise. The reaction mixture was kept at room temperature for $24 \mathrm{hr}$ then iced water was added.The resulting syrup was extracted with petroleum ether (b.p. $40-60$ ${ }^{\circ} \mathrm{C}$ ) , then dried with anhydrous sodium sulphate, filtered and concentrated under reduced pressure. Traces of pyridrne were remove by coevaporation with dry toluene .The benzoate derivative $\underline{(8)}$ was obtained as syrup $(1.6 \mathrm{~g}, 50 \%)$.IR (smear )v $(3100-3000) \mathrm{cm}^{-1}$ (aromatic $\mathrm{C}$ $\mathrm{H}),(1710) \mathrm{cm}^{-1}(\mathrm{C}=\mathrm{O}),(1590) \mathrm{cm}^{-1},(\mathrm{C}-$ C ). Mass spectrum, gave $\mathrm{M}-396$ ( 5 benzoate derivative $\underline{8}$ ) , and $\mathrm{m} / \mathrm{e} 261$ ($\left.\left[\mathrm{phCO}_{2} \mathrm{CH}_{2}\right]\right){ }^{1} \mathrm{H}-\mathrm{NMR} \delta 7.47(\mathrm{~m}, 5 \mathrm{H}$, aromatic ) , $5.95(\mathrm{~d}, 1 \mathrm{H}, \mathrm{H}-1), 4.76-4,63$ (cm, H - 4, H - 5 , H - $5^{\prime}$ ) , 4.58 (d,1H, H 2 ), $4.2\left(\mathrm{~d}, 2 \mathrm{H}, \mathrm{CH}_{2} \mathrm{NO}_{2}\right), 3.95\left(\mathrm{~s}, 2 \mathrm{H}, \mathrm{CH}_{2} \mathrm{NO}_{2}\right)$, $1.50-1.32\left(2 \mathrm{~s}, 6 \mathrm{H}, 2 \mathrm{CH}_{3}\right) \cdot{ }^{13} \mathrm{C}-\mathrm{NMR}$ 8133.31, $130.05,129.85,128.52,128.38$ (aromatic ring carbons ) ,170.62(ph CO ), 105.30 ( C - 1 ), 80.02 ( C - 2),60.49 ( C - 3 ),79.34 ( $\mathrm{C}-4$ ), 77.83 ( $\mathrm{C}-5$ ), 74.88 , $74.62\left(\mathrm{CH}_{2} \mathrm{NO}_{3}\right)$.

1,2 - Di - $\underline{\mathbf{O}}$ - acetyl - 5 - $\underline{\mathbf{O}}-$ Benzoyl - 3 - deoxy - 3,3 - gem - di - $\underline{\mathbf{C}}$ - nitromethyl - a - $\underline{\mathbf{D}}-$ ribofuranosyl bromide (11)

The acetylated sugar $(9)(1 \mathrm{~g}, 2.2 \mathrm{mmol})$ was treated with $50 \%(\mathrm{~W} / \mathrm{V})$ hydrogen bromide in acetic $(3 \mathrm{ml})$ the solution was kept at $0^{\circ} \mathrm{C}$ for one hour then poured in to an ice cooled dichloromethane $(50 \mathrm{ml})$, washed with iced water, and then with saturated aqueous solution of sodium bicarbonate to remove the remaining acid .After a final wash with iced water, the dichloromethane layer was dried over anhydrous sodium sulphate and the solvent was removed to give (11) as syrup $(0.9 \mathrm{~g}, 95 \%)$. The isolated sugar bromide (11) was used directly for the nucleoside synthesis . 
Synthesis of theophylime nucleoside analogue

$\overline{7-(2-\underline{O}}-$ acetyl $-5-\underline{0}-$ benzoyl -3 - deoxy $-3,3$ - gem - di - $\underline{C}-$ nitromethyl $-\beta-\underline{D}-$ ribofuranosyl ) theophyline

The theophylline mercury salt $\underline{(10)}(0.55 \mathrm{~g}$, $0.98 \mathrm{mmol})$ was finely pow dered, suspended in $(150 \mathrm{ml})$ sodium - dried xylene and the solvent was partially distilled to remove traces of water azeotropically. When the temperature of mixture was raised to $137^{\circ} \mathrm{C}$, the residual suspension was allowed to cool (below 50 $\left.{ }^{\circ} \mathrm{C}\right)$. The acetylated sugar bromide (11) $(0.9 \mathrm{gm}, 1.96 \mathrm{mmol})$ in xlyene was then added and the reaction mixture refluxed with vigorous stirring for 15 minute. The xlyene layer was washed with $20 \%$ aqueous potassium iodide to remove the remaining traces of the mercuric salt, washed with water, dried over anhydrous sodium sulphate and the solvent was removed to give after silica gel column chromatography with chloroform as an eluent the acetylated nucleoside $(12)(0.57 \mathrm{~g}, 52 \% \mathrm{Jas}$ syrup .IR (smear) v $(2850-2950) \mathrm{cm}^{-1}(\mathrm{C}-$ $\mathrm{H})$.

Synthesis of protected uracil nucleoside analogue

1 -(2 - $\underline{0}-$ Acetyl - 5 - $\underline{\text { O }}$ - Benzoyl $-3^{\prime}-$ dideoxy $-3^{\prime}, 3^{\prime}-$ gem - di $\underline{\mathbf{C}}-$ nitromethyl $-\beta-\underline{\mathbf{D}}-$ ribofuranosyl $)-4-($ trimethylsily $)$ uracil (14)

The acetylated sugar (9) $(0.44 \mathrm{~g}, 1 \mathrm{mmol})$ and silylated uracil $\underline{(13)}(0.29 \mathrm{~g}, 1.1 \mathrm{mmol})$ were dissolved in anhydrous 1,2 - dichloroethane $(10 \mathrm{ml})$. Anhydrous stannic chloride $(0.08 \mathrm{ml}$, $0.684 \mathrm{mmol}$ ) $\mathrm{w}$ as then added in the presence of few pellets of molecular sieve $4 \mathrm{~A}$ and reaction mixture was stirred at $23{ }^{\circ} \mathrm{C}$, tIc (chloroform - methanol )9:1) showed the reaction was complete after $16 \mathrm{hrs}$. The reaction was then poured on an exess sodium bicarbonate solution and extracted with methylene chloride .The combined methylene chloride extracts was dried over anhydrous sodium sulphate, and the solvent was removed to give (14) $(0.6 \mathrm{~g}, 40,3 \%), \mathrm{IR}$ ( smear $) \mathrm{v}(2850$ $-2950) \mathrm{cm}^{-1}(\mathrm{C}-\mathrm{H}),(3350) \mathrm{cm}^{-1}(\mathrm{~N}-\mathrm{H})$.

The product was purified on silica gel column using chloroform as eluent .Two different fractions were isolated, the first one (14) $(0.018 \mathrm{~g})$ as white semisolid which represented The silyated nucleoside ${ }^{1} \mathrm{H}$ NMR $\delta 7.96$ (s,5H,aromatic ), $7.66-7.64(2 \mathrm{~s}, 2 \mathrm{H}, \mathrm{CH}=\mathrm{CH}$ of uracil ), $4.6-4.4(\mathrm{~cm}, 4 \mathrm{H}, \mathrm{H}-2, \mathrm{H}-4, \mathrm{H}-$ $\left.5, \mathrm{H}-5 \quad{ }^{\prime}\right), \quad 4.2\left(\mathrm{~d}, 4 \mathrm{H}, 2 \mathrm{CH}_{2} \mathrm{NO}_{2}\right), 2.02$ (s $\left., 3 \mathrm{H}, \mathrm{CH}_{3}\right), 0.90\left(\mathrm{~s}, 9 \mathrm{H}, \mathrm{SiMe}_{3}\right)$.The second fraction (14a) $(0.02 \mathrm{mg})$ obtained as syrup identified as the desilylated free nucleoside analogue $\quad{ }_{1}^{1} \mathrm{H} \quad \mathrm{NMR} \quad \delta \quad 8.05 \quad(\mathrm{~m}, 5 \mathrm{H} \quad$, aromatic $), 7.48-7.43 \quad(2 \mathrm{~s}, 2 \mathrm{H}, \mathrm{CH}=\mathrm{CH}$ of uracil $), 5.98(\mathrm{~d}, 1 \mathrm{H}, \mathrm{H}-1), 5.2-4.8(\mathrm{~cm}, 4 \mathrm{H}, \mathrm{H}-$ $\left.2, \mathrm{H}-4, \mathrm{H}-5, \mathrm{H}-5^{\prime}\right), 4.45(\mathrm{~d}, 2 \mathrm{H}$, $\left.\mathrm{CH}_{2} \mathrm{NO}_{2}\right), 3 .\left(\mathrm{d}, 2 \mathrm{H}, \mathrm{CH}_{2} \mathrm{NO}_{2}\right), 2.07\left(\mathrm{~s}, 3 \mathrm{H}, \mathrm{CH}_{3}\right)$. RESULTand DISCUSSION 1.Sythesis of the carbohydrate
moiety of the nucleoside 3 - Deoxy - 1,2 :5,6 - di - O - isopropylidene $-3,3-\mathrm{di}-$ gem $-\mathrm{C}-$ dinitromethyl $-\propto-\mathrm{D}$ - ribofuranose (5) was obtained from D glucose according to the method reported earlier by one of us ${ }^{(7)}$. Selective hydrolysis of the 5,6-isopiopylidene group of the 3,3-gem -di- $\underline{\mathrm{C}}-$ nitrome thyl $-\propto-\underline{\mathrm{D}}-$ ribohexofuranose (5) with in sulphuric acid in methanol ${ }^{(8)}$ gave the monoisoropylidene derivative $\underline{(6)}$ as a syrup in $80.4 \%$ yield .Oxidation of the diol (6) with sodium periodate effected the cleavage of $\mathrm{C}_{5}-\mathrm{C}_{6}$ Bond and resulting intermediate aldehyde derivative was reduced immediately with sodium borohydride to give the 3 - deoxy $-1,2-\underline{\mathrm{O}}-$ is opropylidene $-3,3 \mathrm{gem}-\mathrm{di}-\underline{\mathrm{C}}$ - nitromethyl $-\propto-\mathrm{D}$ - ribofuranose ${ }^{(8)}$. The primary $5-\mathrm{OH}$ group in (7) was then protected by convcrsion to the 5 - benzoate ester (8) . Treatment of (7) with benzoyl chloride in pyridine ${ }^{(9)}$.overnight gave the 5 O-benzoyl-3-deoxy-1,2-O - isopropylidene - 3,3 - gem - di - C - nitromethyl - $\propto-\mathrm{D}-$ ribofuranose $(8)$ as syrup in $50 \%$ yield. The final step in the synthesis of the protected sugar moiety before carrying out the coupling reaction with nucleo-bases, was the removal of $5-\mathrm{O}-1,2-$ acetal of $5-\underline{\mathrm{O}}-$ benzoyl derivative (8) with $99 \%$ trifluoroacetic acid followed by acetylation. Acetylation of the $1-$ and 2 - hydroxyl groups was performed with acetic anhydride in pyridine ${ }^{(9)}$ which afforded $1,2-\mathrm{di}-\mathrm{O}$ - acetyl - $5-\mathrm{O}-$ benzoly $-3-$ deoxy $-3,3-$ gem - di $-\mathrm{C}$ - nitromethyl $-\propto$ $-\mathrm{D}$ - riboturanose $(9)$ as a syrup in $90 \%$ yield .

2- Synthesis of nucleoside analogues

For the synthesis of $7-\left(2^{\prime}-\mathrm{O}-\right.$ acetyl $-5^{\prime}$ - $\underline{\mathrm{O}}$ - benzoyl - 3', $3^{\prime}-\mathrm{di}-\underline{\mathrm{C}}$ - nitrome thyl $\propto-\mathrm{D}$ - ribo - furanosyl ) theophylline (12), the Koenigs - Knorr condens ation method was followed ${ }^{(10)}$. Thus treatment of $1,2-\mathrm{di}-\mathrm{O}-$ acetylrlbofuranose derivative (9) with anhydrous hydrogen bromide in dichloromethane readily afforded $1,2-\mathrm{di}-\mathrm{O}$ bromide(11) which was used immediately because of its instability . 


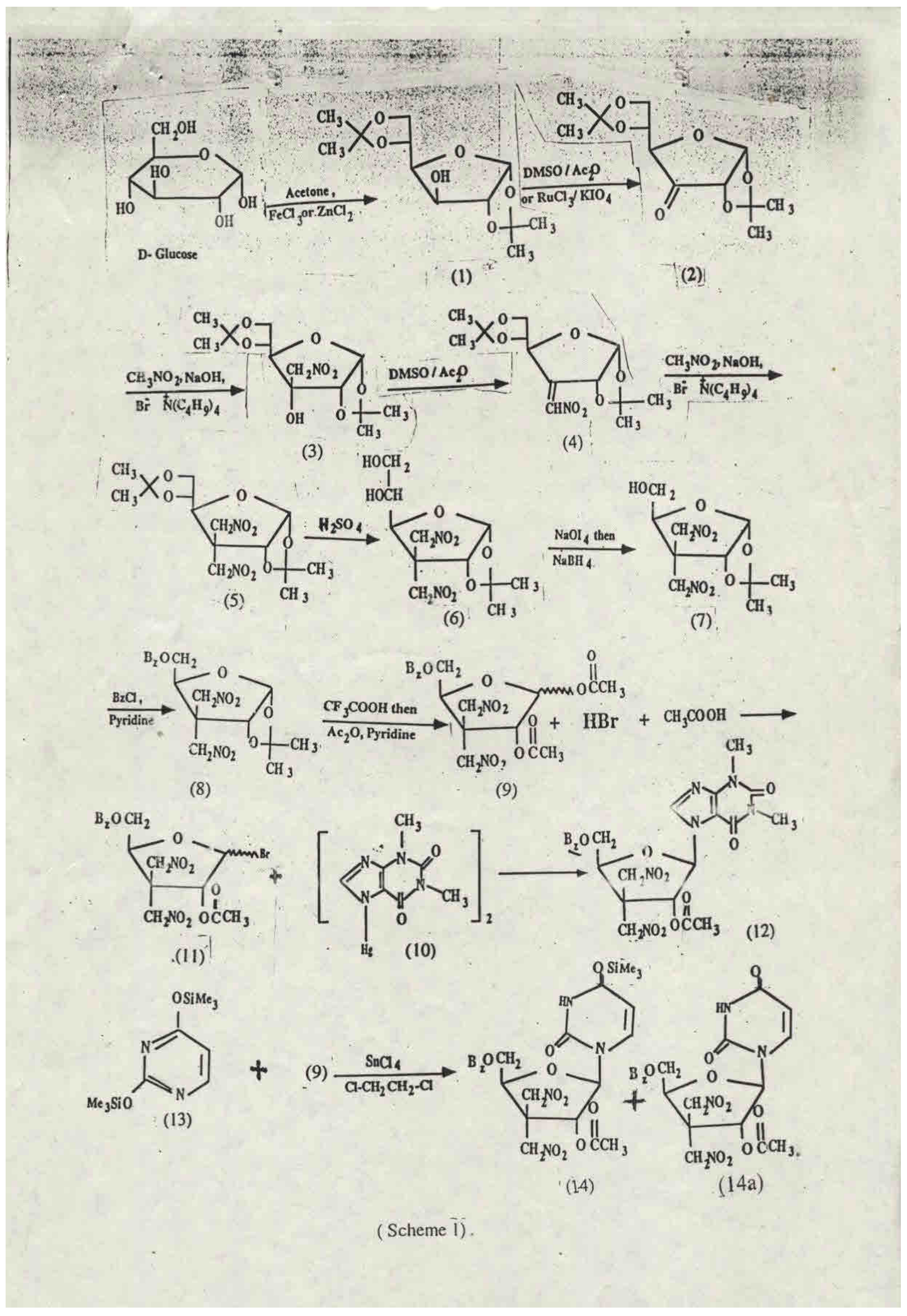


The sugar bromide (11) was condensed with bis (theophylline $-7-\mathrm{yl}$ )mercury $(10)$ as the activated base in anhydrous xylene under reflex which afforded the desired theophylline nucleoside analogue (12), after silica column chromatography, as a syrup in $52 \%$ yield . The theophylline (1,3 - dimethylxanthine )base has been used because of its a vailability and due to the fact that only one of its nitrogen atom ( N 7 ) is reactive , therefore mixture of different nucleoside analogues may be avoided. The reaction of theophylline with mercuric chloride in aqueous alkali afforded the mercury derivative rather than the chloromercury one , and it was assigned that $\mathrm{N}-7$ was the predominate position of attachment of mercury group in the theophylline. It has also been demonstrated that the mercury derivative of theophylline couple with acylglycosyl halides at $\mathrm{N}-7^{(12-14)}$ and involves direct displacement of the mercury group from nitrogen by the incoming acylgycosyl halide ${ }^{(11)}$.

For the synthesis of $1-\left(2^{\prime}-\underline{\mathrm{O}}-\right.$ acetyl $-5^{\prime}$ $-\underline{\mathrm{O}}-$ benzoyl $-3^{\prime}-\operatorname{deoxy}-3^{\prime}, 3^{\prime}-$ gem - di $-\underline{\mathrm{C}}-$ mitromethy $-\beta-\underline{\mathrm{D}}-$ ribofuranose $)-4$ - (trimethylsilyl ) uracil (14), the modified Hilbert - Johnson procedure using simply Friedel - Crafts catalysts like $\mathrm{SnCl}_{4}$ was followed ${ }^{(15)}$. The $1,2-\mathrm{di}-\mathrm{O}-$ aceylribofuranose derivative $(9)$ was coupled with the silylated uracil $\underline{(13)}$ in 1,2 dichoroethane in the presence of anhydrous stannic chloride as Lewis acid .The reaction involved the conversion of the protected sugar $\underline{(9)}$ in to the reactive electrophilic 1,2 acetyloxonium ion followed by the silylated uracil $(13)$ attak to afford the protected uracil nucleoside analogue (14) with the regeneration of the catalyst. The formation of 1,2 acetyloxonium ion determined the exclusive formation of the $-\beta-\operatorname{anomer} \underline{(14)}^{(15-16)}$, which was separated as white semisolid and characterized by its ${ }^{1} \mathrm{H}$ NMR spectrum . Another fraction (14a) was separated on the silica gel column and identified from its ${ }^{1} \mathrm{H}$ NMR spectrum as being the desilylated nucleoside (14a).

\section{REFERENCES}

1. Perigand C.;Gosselin, G.; and lmbach , J.L.,Nucleosides and Nucleotides, 1992 , 11,903 .

2. Wilmon, D.E.V., The Chemistry of Antitumor Agents, Chapman and Hall, New York, 1990, P.261.
3. Harmon, R.E. ,Robins ,R.K, and Town send L.B., Chemistry ' and Biology of Nucleosides, Academic press, Inc. : New York, 1978 ,p . 98

4. Herdewijn, P., Balzarini ,J., Baba, M .,Pauwels, R., Van Aerschot, A., Jaanssen, G. And De Clercq, E., J. MedChem.1988,31,2040 .

5. Herdewijn, P., Balzarini, J., De Clercq . E., Pauwels , R., Baba , M., Broder, S. and Vanderhaleghe, H.,J. Med Chem. . $1987,30,1270$.

6. Huryn , D .M. and Okabe, M., Chem. Rev., 1992, 92,1745 .

7. Ali, Y., Vyas , D.M ., Nabinger , R.C. and Szarek, W.A., Carbohyder Res., 1982, 104 , 183 .

8. Rosenthal, A. and Baker, D.A., J.Org . Chem. 1973, 38 , 193.

9. Rosenthal, A. and Baker, D.A., J.Org . Chem. 1973, 38, 198 .

10. Barton, D. and Oils , W.D., Comprehensive Org. Chem., Vol. 5, $1^{\text {st }}$. Ed., E .Haslam, University of Shcffild , 1979 ; P.60.

11. Montgomery J.A .and Thomas, H.J., J.Org. Chem. , 1966, 31, 1411 .

12. Freestone, A.J., Hough , L. and Richardson , A.C., Carbohydr. Res, ,1973,28,378.

13. Montgomery ,J.A. and Thomas , H.J., Advan. Carbohydr . Chem. 1962, 301, 17 .

14. Montgomery ,J.A. and Thomas . HnJn, J. Org. Chem. , 1963, 28, 2304.

15. Niedballa, U. and Vorbruggen , H,„J .Org.Chem,1974,39,39,3657 .

16. Vorhruggen , H., krolikiewicz , $\mathrm{K}$ - and Bennua , B.,Chem ,Ber .,1981 , 114,1234 .

17. Singh,P.P.,Charia M.M, Dasgupta , F.and Srivastava , H.C ., Tetrahedron Lett ,1977, 5, 439.

18. Glen.W.L.,Myers

G.S.and

Grant,G.A..J.Chem - Soc ., $1951,2568$.

19. Buttcrworth , R.F.; Hanessian ,S - , Synthesis, 1971, 2 ,70 .

20. (a) Ali , Y ; Tawfeek, H.I., Traqi Chem . Soc, Conference, Baghdad March .28-31, 1984 .

(b) Tawfeek .H. I. , M. Sc . Thesis

Sub mitted to the College of Science, University of Baghdad, 1982 .

21. Albrecht ,H.P. and Moffatt , J.G., Tetrahedron Lett., 1970 , 13, 1063 . 